\title{
Parasitoid complex of leaf miner Pyllonorycter comparella (Lepidoptera, Gracillariidae) in Hungary
}

\author{
Levente Sz CS ${ }^{\mathrm{a}^{*}}-$ George MELIKA $^{\mathrm{b}}-$ Csaba THURÓCZY $^{\mathrm{c}}-$ GYörgy CsÓKA $^{\mathrm{a}}$ \\ ${ }^{\text {a }}$ Department of Forest Protection, Forest Research Institute, NARIC, Mátrafüred, Hungary \\ ${ }^{\mathrm{b}}$ Plant Health and Molecular Biology Laboratory, Directorate of Plant Protection, Soil Conservation and \\ Agri-environment, National Food Chain Safety Office, Budapest, Hungary \\ ${ }^{c}$ H-9730 K szeg, Malomárok u. 27, Hungary
}

\begin{abstract}
Between 2011 and 2014, 1,154 mines of Phyllonorycter comparella (Duponchel) were collected at 12 locations in Hungary and were put into single-mine rearing containers. A total of 574 parasitoid specimens belonging to 29 parasitoid species (26 Chalcididae, 2 Encyrtidae and 1 Braconidae) emerged. Of these species, 13 have not yet been mentioned in either international or in Hungarian literature as a parasitoid of the P. comparella. The species assemblages of the parasitoid complexes varied greatly among the sample sites. The primary dominant species of the total samples was found to be Sympiesis sericeicornis (Nees), an abundant idiobiont solitary ectoparasitoid. Among the species reared, we have found specialist parasitoids such as Achrysocharoides scaposa (Erd s) and even species never recorded from Populus (Zagrammosoma variegatum (Masi)) according to the Universal Chalcidoidea Database.
\end{abstract}

Phyllonorycter comparella / Populus alba / parasitoid assemblages

Kivonat-A Populus alba-n él Phyllonorycter comparella (Lepidoptera: Gracillariidae) levélaknázó magyarországi parazitoid együttesei. 1154 Phyllonorycter comparella (Duponchel) levélaknát gy jtöttünk és tettünk egyedi nevelésbe 2011-2014 között, 12 Magyarországi helyszínr 1. A nevelésb 1 kikelt 574 parazitoid egyed alapján 29 fajt (26 Chalcididae, 2 Encyrtidae és 1 Braconidae) sikerült azonosítani. Ezek közül 13 fajt sem a nemzetközi sem a hazai szakirodalom korábbról nem említ, mint a $P$. comparella parazitoidjait. Különböz mintagy jtési helyszínek parazitoid komplexum fajegyüttesében eltérések mutatkoztak. A teljes minta els dleges domináns faja a Sympiesis sericeicornis (Nees), egy gyakori idiobiont szoliter ektoparazitoid volt. A nevelésb 1 kikelt fajok között olyan specialista fajokat is azonosítottunk, mint az Achrysocharoides scaposa (Erd s) valamint Populusról eddig, a Nemzetközi Chalcidoidea Adatbázis (Universal Chalcidoidea Database) által még nem regisztrált Zagrammosoma variegatum (Masi) parazitoid fajt is.

\section{INTRODUCTION}

Phyllonorycter comparella (Duponchel) is a palaearctic species occurring all over the Eurasian continent (De Prins - De Prins 2014). Its main host plant is Populus alba (Gozmány 1956), but it can also be found on Populus tremula (Linné) and Populus $\times$ canescens (Ation) (De Prins - De Prins 2014). It is a bivoltine species; the adults fly from June till August and

\footnotetext{
*Corresponding author: szocsl@erti.hu; H-3232 MÁTRAFÜRED, Hegyalja u. 18.
} 
also in October ( $\mathrm{Sz}$ cs 1977). The species overwinters in the adult stage. The blotch mines are located on the underside of the leaf between the leaf veins (Csóka 2003).

Based on our observations, $P h$. comparella can locally occur at a very high density with several mines on a single leaf. Similar observations have been made by Yedfremova et al. in Russia (Ul'yanovsk Province) in 2007 (Yefremova et al. 2009). A number of papers predict a change in insect behaviour because of the effects of climate change (Cannon 1998, Csóka 1996, Csóka 1997, Dukes et al. 2009, Fleming - Volney 1995, Kirilenko - Sedjo 2007, Walther et al. 2002), and common and even rare species may become severe pests. Therefore, we believe that this species has the potential ability to cause severe outbreaks and possibly heavy damage on Populus alba and Populus $\times$ canescens.

It is always important to study the regulating potential and the species composition of the natural enemy complex of such a species.

The parasitoid complex of Ph. comparella has been inadequately studied thus far. Two of the main parasitoid databases publish a rather small number of parasitoids (De Prins - De Prins 2014, Noyes 2015). In Hungary only two researchers (Erd s 1956, Sz cs 1965, Sz cs 1979) reared parasitoids from $P h$ comparella. The aim of this work is to summarize the knowledge of the parasitoid species developing in Ph. comparella in Hungary in comparison with the data available in European literature.

\section{MATERIAL AND METHODS}

We studied the parasitoid complexes of various leaf miners over a period of four years (20112014). A total of 1,154 leaf mines were collected from $P$. alba at 12 locations across Hungary (Table 1).

Single mine rearings were used. The mines were cut out from the leaf in order to avoid contamination from other parasitoids (i.e. egg or aphid parasitoids) which parasitize other insects on leaves. After a short drying period, the samples were placed individually into air ventilated plastic rearing tubes.

The parasitoids that emerged were preserved in 95\% ethanol, and later identified by Csaba Thuróczy and George Melika. The emerging leaf miner adults were also identified to make sure that the identification of the leaf mines was correct. After the identification process, the adult insects were kept in alcohol for further molecular analysis.

\section{RESULTS AND DISCUSSION}

From the samples collected during the four consequent years (2011-2014), a total of 574 parasitoid specimens emerged from 255 parasitized samples. These specimens belong to 29 parasitoid species (26, 2, and 1 species to the families Chalcididae, Encyrtidae and Braconidae, respectively). The total parasitization rate of our samples was $22.1 \%(n=1154$ samples collected), and at different sample locations (with regard to the sample size) varied between $7.3 \%(\mathrm{n}=55)$ and $75 \%(\mathrm{n}=4)$ (Table 1$)$. 
Table 1. A summary of the sampling locations, the sample sizes and the parasitism rates of our rearings.

WGS84: the coordinates of the sample plots;

TMC: total leaf mines collected; TPM: total parasitized leaf mines;

TSE: total specimen reared; P\%: percentage of parasitism.

\begin{tabular}{|c|c|c|c|c|c|c|c|}
\hline \multirow{2}{*}{ Localities } & \multicolumn{2}{|c|}{ WGS84 (GPS) coordinates } & \multirow{2}{*}{ Sampling date } & \multirow{2}{*}{ TMC } & \multirow{2}{*}{ TPM } & \multirow{2}{*}{ TSE } & \multirow{2}{*}{$\mathbf{P \%}$} \\
\hline & Lat. (N) & Long. (E) & & & & & \\
\hline \multirow[t]{2}{*}{ Ásotthalom } & $46^{\circ} 11^{\prime} 26.90^{\prime \prime}$ & $19^{\circ} 4625.00 "$ & 07.10 .2013 & 147 & 21 & 25 & 14.3 \\
\hline & & & 07.15 .2014 & 238 & 73 & 99 & 30.7 \\
\hline Gödöll & $47^{\circ} 36^{\circ} 06.70^{\prime \prime}$ & $19^{\circ} 24^{\prime} 17.91 "$ & 07.27 .2012 & 3 & 0 & 0 & 0 \\
\hline Gyöngyösoroszi & $47^{\circ} 500^{\prime} 40.45^{\prime}$ & $19^{\circ} 54^{\prime} 03.54 "$ & 08.13 .2012 & 5 & 0 & 0 & 0 \\
\hline Hort & $47^{\circ} 40 ’ 52.51^{\prime \prime}$ & $19^{\circ} 4520.60 "$ & 09.08 .2013 & 4 & 3 & 3 & 75 \\
\hline Jánd & $48^{\circ} 06 ’ 56.28^{\prime \prime}$ & $22^{\circ} 2124.69^{\prime \prime}$ & 06.19 .2013 & 192 & 44 & 256 & 22.9 \\
\hline Kisk rös & $46^{\circ} 35^{\prime} 12.72^{\prime \prime}$ & $19^{\circ} 15^{\prime} 18.75^{\prime \prime}$ & 07.08 .2013 & 17 & 9 & 19 & 52.9 \\
\hline \multirow[t]{2}{*}{ Kiskunhalas } & $46^{\circ} 22^{\prime} 13.47^{\prime \prime}$ & $19^{\circ} 34^{\prime} 03.04 ”$ & 07.13 .2011 & 45 & 17 & 39 & 37.8 \\
\hline & & & 07.15 .2014 & 72 & 12 & 11 & 16.7 \\
\hline \multirow[t]{4}{*}{ Mátrafüred } & $47^{\circ} 49^{\prime} 31.36^{\prime \prime}$ & $19^{\circ} 5828.60 "$ & 06.07 .2011 & 39 & 18 & 22 & 46.2 \\
\hline & & & 06.28 .2011 & 47 & 13 & 28 & 27.7 \\
\hline & & & 06.26 .2012 & 108 & 1 & 5 & 0.9 \\
\hline & & & 06.25 .2013 & 56 & 8 & 8 & 14.3 \\
\hline Poroszló & $47^{\circ} 39^{\prime} 02.11^{\prime \prime}$ & $20^{\circ} 40^{\prime} 25.28^{\prime \prime}$ & 07.11 .2013 & 43 & 8 & 16 & 18.6 \\
\hline Püspökladány & $47^{\circ} 20^{\prime} 04.55^{\prime \prime}$ & $21^{\circ} 0522.83^{\prime \prime}$ & 07.11 .2013 & 55 & 12 & 19 & 21.8 \\
\hline Tatabánya & $47^{\circ} 31^{\prime} 48.96 ”$ & $18^{\mathrm{o}} 25^{\prime} 42.11^{\prime \prime}$ & 10.19 .2013 & 55 & 4 & 7 & 7.3 \\
\hline Törtel & $47^{\circ} 05^{\prime} 15.56^{\prime \prime}$ & $19^{\circ} 5324.33 "$ & 07.08 .2013 & 28 & 14 & 17 & 50 \\
\hline TOTAL & & & & 1,154 & 257 & 574 & 22.3 \\
\hline
\end{tabular}

The identified parasitoid species of the complex is listed in Table 2.

We compared our species list with two of the most important on-line databases, the Universal Chalcidoidea Database, hosted by the British Natural History Museum (Noyes 2015) and the Global Taxonomic Database of Gracillariidae (Lepidoptera), hosted by the Belgian Biodiversity Platform (De Prins - De Prins 2014) and discovered that 15 species found during this research were not listed in these databases as parasitoids of the Ph. comparella.

From the samples collected at Ásotthalom, a total of 124 specimens belonging to 14 species have been identified. The parasitization rate at this place was $24.2 \%$ with 93 parasitized samples. The parasitoid complex was dominated by the synovigenic idiobiont solitary Sympiesis sericeicornis (Nees, 1834) (43\%, $\mathrm{n}=93$ parasitised samples) and Zagrammosoma talitzkii (Boucek, 1961) (12.9\%, n=93). Subdominant species were Pediobius saulius (Walker, 1839) (8.6\%), Minotetrastichus frontalis (Nees, 1834) (8.6\%), Closterocerus trifasciatus (Westwood, 1883) (7.5\%) and a species belonging to the family Braconidae (7.5\%). S. sericeicornis was also dominant at two other locations with small sample sizes (Kisk rös and Törtel) and present in nearly all samples from the 12 sampling locations. Ageniaspis testaceipes (Ratzeburg, 1848), was the dominant species of the samples collected at Jánd ( $\mathrm{n}=192$ total samples collected) causing $43.2 \%$ (from $\mathrm{n}=44$ parasitized samples) of the leaf miner mortality. 
Table 2. The checklist and the number of parasitoid species reared from Phyllonorycter. comparella in Hungary. Species marked with "*” have been recorded for the first time from P. comparella.

\begin{tabular}{|c|c|c|c|c|c|c|c|c|c|c|c|}
\hline Parasitoids reared & 章 & 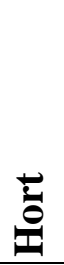 & 胥 & 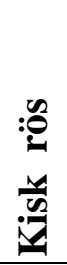 & 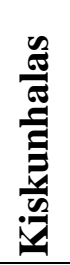 & 窇 & 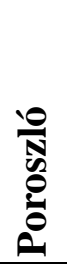 & 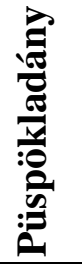 & 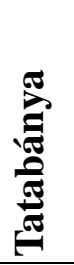 & De & 承 \\
\hline \multicolumn{12}{|l|}{ Encyrtidae } \\
\hline Ageniaspis testacepies* & 23 & & 230 & 11 & & & & 2 & 4 & & 270 \\
\hline Encyrtidae sp.* & & & & & 23 & 24 & & & & & 47 \\
\hline \multicolumn{12}{|l|}{ Eulophidae } \\
\hline Achrysocharoides altilis* & & & & & & 1 & & & & & 1 \\
\hline Achrysocharoides cilla* & & & & & 1 & 15 & & & & & 16 \\
\hline Achrysocharoides scaposa & & & & 1 & & 3 & 12 & 14 & & 4 & 34 \\
\hline Aprostocetus sp. & & & & & 1 & & & & & & 1 \\
\hline Baryscapus nigroviolaceus & 2 & & 2 & & & & & & & & 4 \\
\hline Baryscapus sp. & & & & & 2 & 4 & & & & & 6 \\
\hline Chrysocharis sp. & 2 & & & & & & & & & & 2 \\
\hline Chrysocharis laomedon & & & 3 & & & & & & & & 3 \\
\hline Chrysocharis nephereus & 1 & 1 & & & 1 & & & & & & 3 \\
\hline Chrysocharis pentheus* & 1 & & & & & 1 & & & & & 2 \\
\hline Chrysocharis sp. “A”* & & & & & & & & & 1 & & 1 \\
\hline Cirrospilus elegantissimus & & & 4 & & & 2 & & & & & 6 \\
\hline Cirrospilus lyncus & & & 1 & & 1 & & 1 & & & & 3 \\
\hline Closterocerus trifasciatus* & 8 & & 5 & 1 & 9 & 1 & & & 1 & & 25 \\
\hline Minotetrastichus frontalis & 8 & & 2 & & & & 2 & & & & 12 \\
\hline Neochrysocharis formosus & 5 & 1 & & & & & & & & & 6 \\
\hline Pediobius pyrgo* & & & & & 2 & & & & & & 2 \\
\hline Pediobius saulius & 9 & & 2 & & 2 & 1 & & & & 1 & 15 \\
\hline Pnigalio agraules & & & 2 & & & & & & & & 2 \\
\hline Pnigalio pectinicornis & & & 1 & & & & & & & & 1 \\
\hline Pnigalio soemius* & 1 & & & & & & & & & & 1 \\
\hline Sympiesis acalle* & 1 & & & & & & & & & & 1 \\
\hline Sympiesis dolichogaster* & & & & & & 1 & & & & & $\mathbf{1}$ \\
\hline Sympiesis sericeicornis & 42 & & 3 & 6 & 2 & 9 & 1 & 3 & 1 & 8 & 75 \\
\hline Zagrammosoma talitzkii* & 13 & & & & 6 & & & & & 4 & 23 \\
\hline Zagrammosoma variegatum* & & & & & & 1 & & & & & 1 \\
\hline
\end{tabular}

\section{Braconidae}

Braconidae sp. $\begin{array}{lll}8 & 1 & 1\end{array}$

$\begin{array}{lllllllllll}124 & 3 & 256 & 19 & 50 & 63 & 16 & 19 & 7 & 17 & 574\end{array}$


From the 12 species that were present in these samples, we identified only one parasitoid species belonging to the Braconidae family. At this location, the sub dominant species were C. trifasciatus (11.4\%, $\mathrm{n}=44$ parasitized samples) and Cirrospilus elegantissimus $(9.1 \%$, $\mathrm{n}=44$ parasitized samples). Zagrammosoma talitzkii was dominant in the samples collected at Kiskunhalas, representing $21.4 \%$ of the 28 parasitized samples. The species occurred at only 3 locations. The secondary dominant species of the complex was $C$. trifasciatus $(17.9 \%$, 28 parasitized samples) and an unidentified species from the Encyrtidae family. Achrysocharoides cilla (Walker, 1839) was only dominant in the samples collected at Mátrafüred, being present in $32.5 \%$ of the 40 parasitised samples.

The species also occurred in the samples from Kiskunhalas with an insignificant parasitization rate. The secondary dominant species was $S$. sericeicornis $(22.5 \%, \mathrm{n}=40$ parasitized samples). Achrysocharoides scaposa (Erd s, 1961) was the dominant species at Poroszló (12.5\%, $\mathrm{n}=8$ parasitized samples and 43 total samples collected) and Püspökladány $(17.5 \%, \mathrm{n}=12$ parasitized samples and 55 samples collected) but reared from a relatively small sample size. The species has been observed in samples from five different collecting locations.

The samples from Hort and Tatabánya contained few parasitized samples with only 3 parasitoid species emerged with one specimen each. S. sericeicornis is a solitary idiobiont species and was the most frequent species with a high capacity for controlling the miners. As with $C$. trifasciatus, it has a wide range of hosts and both species can be also be secondary parasitoids (Askew 1979, Stojankovic and Markovic 2005, Noyes 2015).

A more specialized species with a narrow host range, the koinobiont gregarious A. testaceipes, was also abundant, but dominant only at one sample place. According to the Universal Chalcidoidea Database (Noyes 2015) A. scaposa has been reared only from Ph. comparella. We identified the species in 5 of our samples and it was dominant in 2 (Püspökladány and Poroszló).

The gregarious koinobiont $A$. cilla was identified from only 2 sample locations (Kiskunhalas and Mátrafüred). Despite its low abundance within the samples, at Mátrafüred it seems to be the major controlling agent of its host. Zagrammosoma variegatum (Masi, 1907), an idiobiont solitary ectoparasitoid, has never been described from any species living on Populus sp (De Prins and De Prins 2014, Noyes 2015). In our research, we only observed the species at Mátrafüred. At this location we identified another rare and semi-specialist species, Achrysocharoides altilis (Delucchi, 1954).

In $3.5 \%$ of the 257 parasitized mines we found more than one species of coexisting parasitoids. On these rare occasions, both parasitoid species/specimens are able to complete the larval development. Such events/phenomena are termed the coexistence of multiple parasitoids, a phenomenon among parasitoids of various insects that is well known and has been documented for a long time (Askew - Shaw 1979, Amarasekare 2000a, Amarasekare 2000b, Klapwijk Owent 2011, Borer et al. 2004, Hackett-Jones et al. 2009, László - Tóthmérész 2013). The coexistence of two parasitoids foraging on a single host occurs when the distribution of the parasitoids is sufficiently aggregated (May and Hussel 1981, Klopfer and Ives 1997), which triggers intra and interspecific competition (MacArthur and Levins 1967). The successful development of the parasitoids on a single host requires the partitioning or sharing of the food resource (Harvey et al. 2013) by partial host consumption (Miller 1982) and/or the separation of the temporal niche (Hackett-Jones et al. 2009, Amarasekare 2000a) In this case, the competition between the parasitoid species is delimited by the earlier mentioned requirements.

In our samples we registered 9 cases of multiple parasitism. In most cases (6 of 9) the parasitoid couple was composed from a koinobiont and an idiobiont parasitoid, where the koinobiont is a primary parasitoid and the idiobiont is a secondary generalist parasitoid. Therefore, we might say that it is likely that the first (primary) encounter could be the 
koinobiont endoparasitoid. On one occasion, we registered two idiobiont ectoparasitoids that had completed their stages.

The most surprising finding was the presence of three koinobiont species from a single mine, which is a rather rare event (Askew 1979, Miller 1982).

Next follows a brief overview on the biology of the parasitoid pairs emerged from single mines (abbreviations: $\mathrm{En}=$ endoparasitoid; $\mathrm{Ec}=$ ectroparasitoid; $\mathrm{G}=$ gregarious; $\mathrm{S}=$ solitary; $\mathrm{K}=$ koinobiont; $\mathrm{I}=$ idiobiont. Read as follows: En, $\mathrm{G}, \mathrm{K}=$ Endoparasitoid, Gregarious, Koinobiont):

- 1 female specimen of Achrysocharoides altilis $($ En, $, \mathrm{G}, \mathrm{K})+$

1 male specimen of Baryscapus sp. (Ec,G,I)

- 1 female specimen of Braconidae (En,S,K) + 1 male specimen of Pnigalio agraules (Ec,S,I)

- 2 female specimens of Achrysocharoides scaposa $(\mathrm{En}, \mathrm{G}, \mathrm{K})+$ 1 female and 1 male specimen of Minotetrastichus frontalis (Ec,G,I)

- 1 male specimen of Baryscapus nigroviolaceus $(\mathrm{En}, \mathrm{S}, \mathrm{K})+$ 1 female specimen of Minotetrastichus frontalis $(\mathrm{Ec}, \mathrm{G}, \mathrm{I})$

- 1 female specimen of Chrysocharis nephereus $(\mathrm{En}, \mathrm{S}, \mathrm{K})+$ 1 female specimen of Pnigalio soemius (Ec,S,I)

- 1 male specimen of Pediobius saulius $(\mathrm{En}, \mathrm{S}, \mathrm{K})+$ 1 female specimen of Zagrammosoma talitzkii (Ec,S,I)

- 1 female specimen of Braconidae (En,S,K) + 1 female specimen of Minotetrastichus frontalis (Ec,G,I)

- 1 female specimen of Zagrammosoma talitzkii (Ec,S,I) + 1 male specimen of Sympiesis sericeicornis (Ec,S,I)

- 1 female specimen of Chrysocharis nephereus $(\mathrm{En}, \mathrm{S}, \mathrm{K})+$ 1 female specimen of Neochrysocharis formosus (En,G,K) + 1 male specimen of Braconidae (En,S,K).

The two relevant online databases (Noyes 2015, De prins and De Prins 2014) list only a small number (19) of parasitoid species associated with the $P$. comparella, reflecting a small amount of studies regarding species load of the leaf miners parasitoid complexes. In this work we contribute 13 species of parasitoids as first records for the host Phyllnorycter comparella. Overall, we summarize that 36 parasitoid species have been recorded from $P h$. comparella so far, including 29 species listed in the present publication. The species composition of the parasitoid complexes of sample sites varied greatly. It is acceptable to say that the parasitoid species of the leaf miner presented a habitat-specific occurrence as found by Hawkins (1994) and Gibbson et al. (1997). Common species, with a generally wide host range, being abundant in nearly all places represented the highest number of species of the entire complex (18 species) .The endoparasitoid species, like the A. testasceipes, had the biggest impact on the leaf miner $P$. comparella.

As found at the sample sites, the $P h$. comparella leaf miner can sometimes be very abundant (Yefremova 2009, personal observation). Climate change might trigger outbreaks of this species (as seen with other insects), causing heavy damage to its host plant (Kyle et al. 2014).

Nowadays many forests are composed from a low diversity of trees due to economic forest use; this low diversity of trees may help to intensify the outbreaks of many species (Jactel and Brockerhoff 2007). A number of papers show that diverse habitats contain more complex food-webs with a number of natural enemy species (Paine 1966, Polis and Strong 1996). It is always important to study the species composition of both native (Sz cs et al. 2013) and invasive (Sz cs et al. 2014) species with outbreak ability. 
Acknowledgements: This project was supported by the OTKA (Hungarian Scientific Research Grant) 84096 research grant and by the Silva naturalis - Investigation of continuous forest cover in ecological, conservational biological, public welfare and nature conservational aspects TAMOP-4.2.2.A-11/1/KONV-2012-0004 project sponsored by the EU and the European Social Foundation. We are grateful to Csaba Szabóky (Budapest) for his help in confirming the identification of the leaf miner adults.

\section{REFERENCES}

AMARASEKARE, P. (2000a): Coexistence of competing parasitoids on a patchily distributed host: local vs. spatial mechanisms. Ecology, 81 (5): 1286-1296.

AMARASEKARE, P. (2000b): Spatial dynamics in a host-multiparasitoid community. Journal of Animal Ecology, 69(2): 201-213. DOI:10.1046/j.1365-2656.2000.00378.x

ASKEW, R.R. - SHAW, M.R. (1979): Mortality factors affecting the leaf-mining stages of Phyllonorycter (Lepidoptera: Gracillariidae) on oak and birch. 2. Biology of the parasite species. Zoological Journal of the Linnean Society 67: 51-64

BORER, E. T. - MURDOCH, W. W. - SWARBRICK, S. R. (2004): Parasitoid coexistence: linking spatial field patterns with mechanism. Ecology 85 (3): 667-678.

CANNON, R. J. C. (1998): The implications of predicted climate change for insect pests in the UK, with emphasis on non-indigenous species. Global Change Biology, 4: 785-796. DOI: $10.1046 / \mathrm{j} .1365-2486.1998 .00190 . \mathrm{x}$

CsóKA Gy. (1996): Aszályos évek - fokozódó rovarkárok erdeinkben. [Years of drought - increasing damage by forest insects]. Növényvédelem, 32 (11): 545-551. (in Hungarian)

CsóKA, Gy. (1997): Increased insect damage in Hungarian forests under drought impact. Biologia 52 (2): 159-162.

CsÓKA, Gy. (2003): Levélaknák és levélaknázók [Leaf mines and leaf miners]. Agroinform Kiadó és Nyomda, Budapest. 192 p. (in Hungarian)

De PRINS, J. - De PRINS, W. (2014): Global Taxonomic Database of Gracillariidae (Lepidoptera). World Wide Web electronic publication (http://www.gracillariidae.net) [15.02.2015].

DuKES, J. S. - PONTIUS, J. - ORWIG, D. - GARNAS, J. R. - RodGeRS, V. L. - BRAZEE, N. - COOKE, B. TheOHARIDES, K. A. - StANGe, E. E. - HARRINGTON, R. - Ehrenfeld, J. - GuREVITCH, J. LERDAU, M. - Stinson, K. - WICK, R. - AYRES, M. (2009): Responses of insect pests, pathogens, and invasive plant species to climate change in the forests of northeastern North America: What can we predict? This article is one of a selection of papers from NE Forests 2100: A Synthesis of Climate Change Impacts on Forests of the Northeastern US and Eastern Canada. Canadian Journal of Forest Research 39: 231-248. doi:10.1139/X08-171

ERD S, J. (1956): Additamenta ad cognitionem faunae Chalcidoidarum in Hungaria et regionibus finitimis. VI. 19. Eulophidae. Folia Entomologica Hungarica (Series Nova) 9 (1): 1-64.

Fleming, R. A. - VOLNEY, W. J. A. (1995): Effects of climate change on insect defoliator population processes in Canada's boreal forest: Some plausible scenarios. Water, Air, and Soil Pollution 82: 445-454. DOI:10.1007/BF01182854

Polis, G. A. - Strong, D. R. (1996): Food web complexity and community dynamnics. The American Naturalist. (147)5: 813-846.

Gibson, G. A. P. - Huber, J. T. - Woolley, J. B. (1997): Annotated keys to the genera of Nearctic Chalcidoidea (Hymenoptera). NRC Research Press, Ottawa, Ontario. 794 p.

GOZMÁNY L. (1956): Molylepkék II - Microlepidoptera II. Magyarország állatvilága - Fauna Hungariae 16 (3).

HacketT-Jones, E. - Cobbold, C. - White, A. (2009): Coexistence of multiple parasitoids on a single host due to differences in parasitoid phenology. Theoretical Ecology 2(1): 19-31. DOI:10.1007/s12080-008-0025-1

HARVEY, J. A. - POELMAN, E. H. - TANAKA, T. (2013): Intrinsic inter- and intraspecific competition in parasitoid wasps. Annual Review of Entomology 58: 333-351. DOI:10.1146/annurev-ento$120811-153622$ 
JACTEL, H. AND BROCKERHOFF, E.G. (2007): Tree diversity reduces herbivory by forest insects. Ecology Letters 10: 835-848.

KYLE, J. H. - ANDREW, J. A. AND DIETERICH K. (2014): Forest defoliator outbreaks under climate change: effects on the frequency and severity of outbreaks of five pine insect pests. Global Change Biology. 20: 2004-2018.

KiRILENKO, A. P. - SEDJO, R. A. (2007): Climate change impacts on forestry. Proceedings of the National Academy of Sciences of the United States of America. 104(50): 697-702. DOI:10.1073/pnas.0701424104

KLAPWIJK, M. J. - OWENT, L. (2011): Spatial ecology of multiple parasitoids of a patchily-distributed host: implications for species coexistence. Ecological Entomology 36(2): 212-220. DOI:10.1111/j.1365-2311.2011.01261.x

LÁSZLÓ, Z. - TÓTHMÉRÉSZ, B. (2013): Landscape and local effects on multiparasitoid coexistence. Insect Conservation and Diversity 6 (3): 354-364. DOI:10.1111/j.1752-4598.2012.00225.x

MACARTHUR, R. H. AND LEVINS, R. (1967): The limiting similarity, convergence and divergence of coexisting species. Am Nat 101:377-385.

MAY, R. M. AND HASSELL, M. P. (1981): The dynamics of multiparasitoid- host interactions. Am Nat 117(3): 234-261.

KLOPFER, ED AND IVES, A.R .(1997): Aggregation and the coexistence of competing parasitoid species. Theor Popul Biol 52(3): 167-178.

MiLlER, J. C. (1982): Life History of Insect Parasitoids Involved in Successful Multiparasitism. Oecologia 54: 8-9.

NoYeS, J. S. (2015): Universal Chalcidoidea Database. World Wide Web electronic publication. http://www.nhm.ac.uk/research-curation/research/projects/chalcidoids/database/. Accessed 19 February 2015

PAINE, R. T. (1966): Food web complexity and species diversity. The American Naturalist 100 (910): $65-75$.

StOJANOVIĆ, A. AND MARKOVIĆ, Č. (2005): Parasitoid complex of Phyllonorycter robiniella (Clemens, 1859) (Lepidoptera, Gracillaridae) in Serbia. Journal of Pest Science, 78: 109-114.

Sz CS, J. (1965): The parasites of mining moths. Folia Entomologica Hungarica (Series Nova) 18 (7): $123-151$.

Sz CS J. (1977): Lepidoptera -aknák és -gubacsok Hyponomia et Cecidia Lepidopterorum. Magyarország állatvilága - Fauna Hungariae 16. Budapest: Akadémiai Kiadó.

SZ CS, J. (1979): Angaben zu den Parasiten der minirenden Motten (Hymenoptera: Braconidae). Folia Entomologica Hungarica (Series Nova) 32 (2): 199-206.

Sz CS L. - MelikA G. - CsóKA G. (2013): Adatok a hazai tölgyeken el forduló levélaknázók parazitoid együtteseinek ismeretéhez. [Data on the parasitoid complexes of leaf mining insects on oaks]. Erdészettudományi Közlemények 3(1): 251-259. (in Hungarian)

Sz CS L. - MELIKA G. - THURÓCZY C. - CsóKA Gy. (2014): Adatok az invázív hárslevél sátorosmoly (Phyllonorycter issikii KUMATA, 1963) Magyarországi parazitoid együtteseinek ismeretéhez. [Data on the parasitoid complexes of the lime leaf miner moth (Phyllonorycter issikii (Kumata, 1963)]. Növényvédelem 50(10): 445-451. (in Hungarian)

Walther, G.-R. - Post, E. - Convey, P. - Menzel, A. - Parmesan, C. - Beebee, T.J.C. Fromentin, J.-M. - Hoegh-GuldBerg, O. - BAirlein, F. (2002): Ecological responses to recent climate change. Nature 416, 389-395. DOI:10.1038/416389a 